\title{
Correction to: The pricing of European non-performing real estate loan portfolios: evidence on stock market evaluation of complex asset sales
}

\author{
Florian Manz ${ }^{1} \cdot$ Birgit Müller $^{1} \cdot$ Dirk Schiereck $^{1}$
}

(c) The Author(s) 2021

\section{Correction to: Journal of Business Economics (2020) 90:1087-1120 https://doi.org/10.1007/s11573-020-00983-1}

The article "The pricing of European non-performing real estate loan portfolios: evidence on stock market evaluation of complex asset sales, written by Florian Manz · Birgit Müller · Dirk Schiereck, was originally published Online First without Open Access. After publication in volume 90, issue 7, pages 1087-1120 the author decided to opt for Open Choice and to make the article an Open Access publication. Therefore, the copyright of the article has been changed to (C) The Author(s) 2021 and the article is forthwith distributed under the terms of the Creative Commons Attribution 4.0 International License, which permits use, sharing, adaptation, distribution and reproduction in any medium or format, as long as you give appropriate credit to the original author(s) and the source, provide a link to the Creative Commons licence, and indicate if changes were made. The images or other third party material in this article are included in the article's Creative Commons licence, unless indicated otherwise in a credit line to the material. If material is not included in the article's Creative Commons licence and your intended use is not permitted by statutory regulation or exceeds the permitted use, you will need to obtain permission directly from the copyright holder. To view a copy of this licence, visit http://creat ivecommons.org/licenses/by/4.0/.

The original article can be found online at https://doi.org/10.1007/s11573-020-00983-1.

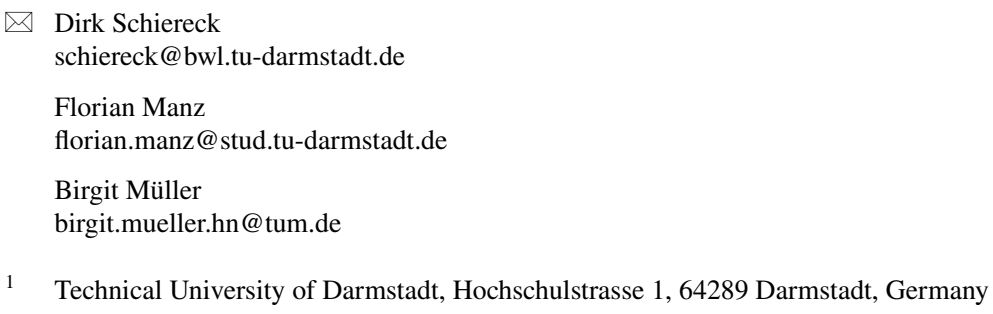


Open Access This article is licensed under a Creative Commons Attribution 4.0 International License, which permits use, sharing, adaptation, distribution and reproduction in any medium or format, as long as you give appropriate credit to the original author(s) and the source, provide a link to the Creative Commons licence, and indicate if changes were made. The images or other third party material in this article are included in the article's Creative Commons licence, unless indicated otherwise in a credit line to the material. If material is not included in the article's Creative Commons licence and your intended use is not permitted by statutory regulation or exceeds the permitted use, you will need to obtain permission directly from the copyright holder. To view a copy of this licence, visit http://creativecommons.org/licen ses/by/4.0/.

Publisher's Note Springer Nature remains neutral with regard to jurisdictional claims in published maps and institutional affiliations. 